\title{
The notion of participatory democracy in relation to local ward committees: The distribution of power
}

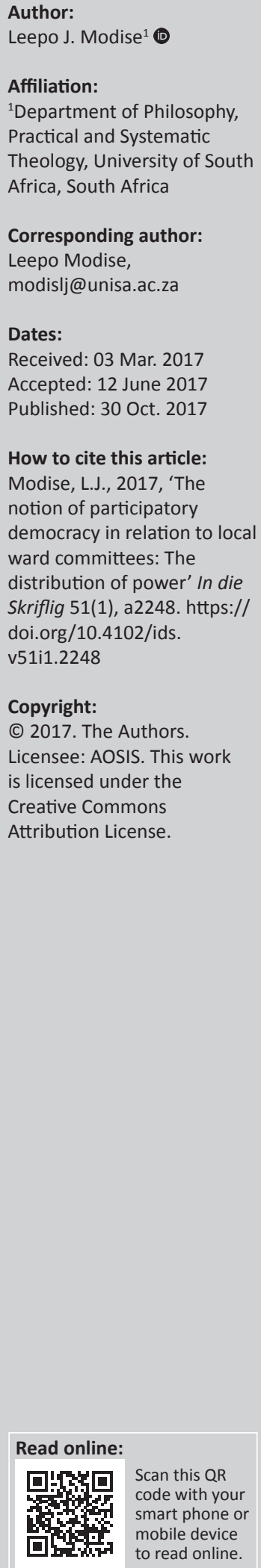

This article comprises four important parts: first, the two important components of democracy, namely participatory and non-participatory or representative democracy will be discussed with special reference to the distribution of powers. Second, it will address the roles and responsibilities of ward committees within the democratic society. Third, the ethical question of the basis of the committee members' capacity to serve on the ward committees in relation to coercive leadership (tyranny of the majority) will be investigated. Fourth, the theological standpoint on the distribution of powers or participatory democracy and the role of the church to improve participatory democracy will be discussed. The research question is the following: What can be done by the country to improve participatory democracy in South Africa, through engagement with ward committees?

\section{Introduction}

Participatory democracy is a great challenge for democratic South Africa due to the lack of adequate knowledge of citizens about political operation locally and internationally. The service delivery protests and marches are a clear indication that participatory democracy is a great challenge in democratic South Africa. Craythorne (2006:36) declared that local government is of supreme importance in many instances. It is also the circle of government closest to all the people of South Africa and is constitutionally responsible for providing a series of services without which people would be forced to live in hopeless poverty and depression. Hence, the provincial and national government need to offer supervision, support, mentorship and assistance where necessary. The people, through their ward committees, need to inform the local government and politicians about their needs. The Integrated Development Plan (IDP) as well as the local, district, provincial and national government must be informed of the people's needs. Throughout the article the focus will be on the following notions: democracy with special reference to the distribution of powers; the capacity of ward committee members to carry out their roles and responsibilities; and the theological standpoint on the distribution of powers.

\section{The problem statement in this article}

Democratic South Africa, by virtue of its constitution, is a mixture of participatory and representative democracy where the people elect their representatives at different circles of government - local, provincial and national. The problem arises when greed, ego-centrism, favouritism and nepotism occur. When these unethical behaviours take over, these representatives forget about the people on the grass-root and, as a result, participatory democracy disappears. The South African Constitution (Republic of South Africa 1996) also makes provision for the ward committees to enhance participatory democracy, but these structures are taken over by the tyranny of the majority or cohesive leadership styles of the representative government.

The problem statement here is dual:

- Representative democracy in South Africa engulfed participatory democracy just after the elections. The active participation of the people of South Africa in their governance was maximised during the election period and minimised after the elections. This means that after the election the parliamentary democracy took over the participatory democracy. Just a few people took the decisions on behalf of the entire nation. Service delivery protest is the result of the lack of reaching out to the people.

- The baseline governance in the democratic system is people at grassroots level. This means that the structural government ought to focus its energy to where the people are located. There ought to be structures for people to consult and voice their problems right from the streets, wards and local communities. A selection of these structures needs to be done carefully so that 
it represents the people rather than officials and politicians. Qualification and character of people selected to be in these positions should be taken into consideration.

The research question based on the above-mentioned dual problem statement is the following: What can be done to enhance participatory democracy in South Africa?

The following are sub-questions:

- What is the difference between these two types of democracies?

- How to enhance participatory democracy in the South African context?

- What are the roles and responsibilities of ward committees?

- What qualities are needed for ward committee members to perform their roles effectively?

\section{Aims of this article}

The aims of this article will focus on the above-mentioned research question:

- To determine from the literature what participatory and representative democracy is;

- To illustrate how the South African Constitution (Republic of South Africa 1996) enhanced participatory democracy;

- To determine from the literature the roles and responsibilities of ward committees in South Africa;

- To determine how theology can be used to minimise the tyranny of the majority through the distribution of power.

\section{Approach and research method employed in this article}

The approach this article follows is descriptive-normative. ${ }^{1}$ Concepts like equality, human dignity, democracy and distribution of power also fall within the political theology. The question is how modern political theory is covertly a form of secularised theology (Hunsinger 2012:271). Political theology refers to the democratic expression of a political relativism and a scientific orientation that are liberated from miracles and dogmas, and based on human understanding and critical doubt. Metz (2012:319) describes political theology as a new theology that sees eco-socio-political crises as fundamental predicaments of theology and that attempts to overcome them in productive reduction. It is a science that engages theological thinking based on the life experience of the people at grassroots level. According to political theology, theology must come to terms with the denials of historical innocence through historicism and with the denial of its social innocence through ideological criticism in both its bourgeois and its

1.Political theology falls into two general categories, namely the descriptive and normative. They need not be mutually exclusive. Descriptive accounts may have a normative agenda, while normative accounts usually incorporate elements of political description. Descriptive accounts look at how theology functions in politica contexts and how normative accounts ought to function. Normative accounts usually assume that the right kind of theology correlates with the right kind of political function $(+/+)$, and the wrong kind of theology with the wrong kind of function $(-/-)$. The mixed possibilities, however, are rarely entertained. However, in actuality, as a human imperfection or inconsistency, the right kind of theology may actuality, as a human imperfection or inconsistency, the right kind of theology may
correlate with the wrong kind of function $(+/-)$; and the wrong kind of theology with correlate with the wrong kind of function (+/-); and the
the right kind of function $(-/+)$ (Hunsinger 2012:271).
Marxist versions. Theology can no longer push the questions invoked here away from its centre in to the fringe zones of apologetics. It is the very responsibility of theology to address these crises (Metz 2012:319). Hence, the political theology tools has been followed in this article by analysis and interpret: What is happening (descriptive) or what ought to happen (normative) in democratic South Africa?

\section{The notion of South African democracy in terms of its constitution}

According to the South African Constitution (Republic of South Africa 1996), South Africa is one united, autonomous, democratic state originated on the following values: human dignity, equality, advancement of human rights and freedoms, non-racialism and non-sexism, supremacy of the Constitution and the rule of law, universal adult suffrage, a national common voters roll, regular elections, and a multiparty system of democratic government to ensure accountability, responsiveness and openness (Republic of South Africa 1996:3). There is an illustration from the Constitution of the Republic of South Africa (1996) that this country is a democratic state that ought to be continuously participatory in nature as is illustrated in the above values of the constitution. The effectiveness and efficiency of this participatory democracy as against representative democracy will be investigated from the ward committee perspective.

\section{Schmidt (2002:98) postulates that:}

democracy is the collective term for the wide diversity of democratic systems that includes radical democracies as well as moderate ones, representative and direct democracy, parliamentary democracy versus presidential government, majoritarian and consensus democracy and established democracies as opposed to partial democracies. (p. 98)

The logo of the democratic system is 'government of the people, by the people' (or elected representatives of the people) or 'government for the people'. Practical governance in a democratic system differs from one democracy to another. In this section the focus will be on the unfolding of representative democracies over participatory democracies via the election of the government by the people who mandate the politicians to govern the people instead of the people governing themselves. The biggest part of the South African democracy is representative of nature where the people are represented by the politicians of their choice to form a government structure: the local, provincial and national government. The people are expected to express their views via the baseline governance, which is local government (ward committee as the functional organ) or the Chapter 9 institutions (Republic of South Africa 1996).

\section{The notion of participatory democracy as a form of citizens' engagement in governance}

After 22 years of the establishment of the South African electoral democracy on 27 April 1994, the country has 
currently established an arrangement of tentative multidimensional participatory democracy situated within a base framework of constitutional and electoral democracy. It is, however, extended through a relatively wide variety of initiatives that have introduced multiple levels of engagement between the government and citizens' engagement that has impacted on most of the parts of political and policy decision making.

Theoretically and ideologically 'democracy' refers to the state system in which sovereignty is officially invested in the people or citizens (Raadschelders 2003:98). I concur with Raadschelders (2003) that democracy is the business of the people and the people's engagement in the governance of the country. Right from the ward level to the national level the voice of the people ought to be echoed in the actions of the government and politicians. The sovereignty of the state system will be invested in the people. This implies direct participation in the affairs of the state and it will create a conducive environment. This conducive environment ought to be the local government where the majority of people are residing. In this sense participatory democracy is essentially about the question whether or how citizens should be given the right to participate in decision making that affect them, notwithstanding the fact that the basic form of political organisation in the modern nation-state is, and is likely to remain, representative democracy.

Furthermore, Raadschelders (2003:100) argues in response to the above question that local government ought to be a learning institution for democracy in the situation of local figures. Besides, having the purpose of electing, many citizens, in turn, have the chance of being elected and many, either by selection or by rotation, fill one or other of the numerous local executive positions. In these offices, they have to act, think and speak in the interest of the public and the thinking cannot all be done by delegation. It should be added that these local functions, which are not widely welcomed by the higher structures, carry the important political education that enables them to grant assistance to a much lower level in society (Raadschelders 2003:100).

The people should participate in the thinking and speaking process to enhance their interests or aspiration; they should not delegate official duties to the representatives of the people. The representatives should be the mouthpiece of the people. Drawing from the argument above, the comprehensive perspective is that democracy should include direct participation in local community institutions, active control of elected politicians through the party system and social as well as economic rights to ensure adequate resources for the people's political activity In the context of this research the best baseline participation in the local communities will be in the ward committees where robust discussions and decision making will take place through a small, manageable group of people.

The period between 1994 and 2016, as a whole, was characterised by a sequence of overlapping standards that illuminate the potential deepening of South African participatory democracy. This developing of participatory democracy is illustrated by various interfaces between communities and their elected representatives. Municipal ward committees are a mechanism of participation and engagement between government and the citizens at local government level (Venter \& Landsberg 2011:7). Municipal ward committees will be influenced by South Africans' experiences of the deepening of participatory democracy and their experiences of opportunities for engagement as well as the impression that their participation in the 1994/1996 and post-1996 innovations have had, in founding and emerging, channels for continuous democratic engagement. South African participatory democracy is overpowered by representative democracy. During the election the people mandated politicians from different political parties to represent their aspirations and needs. This participation is obtained through the ballot. Thereafter, the representative democracy is maximized at the expenses of participatory democracy. The norm is that participatory democracy should have the same weight as representative democracy, but it overshadow participatory democracy.

\section{The notion of representative democracy as a basic form of political organization}

Representative democracy is a form of democracy in which citizens allow others - usually elected officials - to represent them in government processes and in which they are not necessarily directly involved in the processes of law-making or decision-making. This form of democracy has become especially popular in regions where the number of citizens is so large that direct representation would become overly complicated and cumbersome. Some people believe that one of the shortcomings of representative democracy is that the representatives might not properly serve the people who they are supposed to represent. In representative democracies, the representatives typically serve in chambers such as the senate, parliament, House of Representatives or similar government bodies. Representative democracy allows citizens to elect individual members of the community who will deal with the responsibilities and tasks of governance and decision making on their behalf. This might appear to create unnecessary separation between the people and the laws that are being made, but the intention is that the representatives should receive the necessary education and training to enable them to understand the complicated needs of their jurisdiction.

Some people believe that in a representative democracy, it would be ideal for the elected officials to have a certain level of political education to equip them with knowledge and interest to deal with social and governmental challenges. In many cases, however, representatives are often elected on the basis of shared beliefs and opinions of certain segments of the populace, regardless of those representatives' education, knowledge, integrity or ability to solve problems. This is seen by some people as a weakness of representative democracy in that the representatives might place their own needs and preferences before those of the people. Proponents of representative 
democracy often point to the fact that the citizens choose the representatives by direct election and, by doing so, they ultimately help decide what will be made into law.

Representative democracy without the engagement of citizens is incomplete, because governance means service to the people. Service to the people means interactions and interrelationships between the elected representatives and the people. These interactions and relationships are clearly stipulated in the South African Constitution (Republic of South Africa 1996) and the Municipal Systems Act 32 (Republic of South Africa 2000) in an attempt to satisfy citizens to delegate their interests to elected members of the government across the respective spheres. Representation or representational participation are terms used in this regard. It relates to the notion of indirect or direct representative democracy.

\section{The notion of distribution of power as participatory}

In this article the notion of the distribution of power as participatory democracy will be discussed from the theological perspective. It will be argued from the confessional basis, theological ethics and public administration. The Belgic Confession (1561) will be chosen as the point of departure, because it is the only confession that states the relationship between the church and state. It will also be the point of departure for distribution of power and it is from where the argument will develop towards theological ethics and public administration.

The Belgic Confession (1561) states in article 36 that, because of the depravity of the human race, the triune God has ordained kings (presidents), princes and civil officers in order to protect God's creation and to give order when there is disorder. God requests the world to be run by laws and policies so that human affairs may be conducted in an orderly manner. Bonhoeffer (2012) indicates that:

The Reformation does not represent the traces of this idea, too, can be found in the writings of some of the Reformers; it places the origin of the state, as government in the Fall. It was sin that made necessary the divine institution of government. The sword which God has given to the government is to be used by it in order to protect men against the chaos which is caused by sin. Government is to punish the criminal and to safeguard life. (p. 288)

For that tenacity God has placed a sword in the hands of the government to punish evil human beings and protect the good. The government's task is not limited to caring for and watching over the public domain. A confession as a statement of faith as well as each and every other confession is born out of doubt of a particular teaching, philosophy or action of its time. It is interesting to note that God has ordained the government officials, but it is equally interesting to note that government officials are fallible human beings. Hence, participatory democracy is encouraged in the sense that the government should not be on the shoulders of one person who can abuse that power. Habermas (1994:1), when critiquing centralised power, postulates that politics is viewed as the reflective form of substantial ethical life, namely as the medium in which the members of somehow solitary communities become aware of their dependence on one another and, acting with full deliberation as citizens, further shape and develop existing relations of reciprocal recognition into an association of free and equal consociates under law. With this, the liberal architectonic of government and society undergoes an important change: in addition to the hierarchical regulations of the state and the decentralised regulations of the market, that is, besides administrative power and individual personal interests, solidarity and the orientation to the common good appear as a third source of social integration.

On the same note Bonhoeffer (2012:300) argues that individual Christians cannot be made responsible for the action of the government. They must not make themselves responsible for this, but, because of their faith and charity, they are responsible for their own calling and for the sphere of their own personal lives - no matter how big or small it may be. If this responsibility is fulfilled in faith, it is effectual for the whole of the city or state. This way every individual, in reality, serves government with his or her responsibility. No one, not even the government itself, can deprived an individual of this responsibility or forbid him or her to discharge it, for it is an integral part of life in sanctification, and it arises from obedience to the Lord of both church and government. Bonhoeffer (2012:300) encourages participation of the people in the government. Participatory democracy, on the other hand, allows all spheres of government, stakeholders and all people at grassroots level to participate in the governance of the people as stewards of God in the universe.

Thielicke (1969:210) states that authority and confidence, as revenue of imperfect power, are by nature moral objects. In that sense, they cannot be compulsory for the people, because they are limited (depravity of the human race). In the same score, one is convinced that they may not exist. There is a possibility that there can be a government without authority and confidence, because by nature, they are moral entities that cannot be forced. For example, in the form of terror, it can be an overpowering force which has taken on a monopolistic character. The possibility exists that authority and confidence is not present to ensure the control of power and it is a recognised fact that the power is dangerous and human beings tend to abuse it. Therefore, power becomes necessary to consider institutional safeguards to prevent such abuse. The device that political theorists and constitutions use to limit power and prevent its abuse is usually called distribution of powers (Thielicke 1969:210).

Drawing from a theological perspective, one might suggest that the distribution of power is an institutional appearance of a persisting mistrust of power or rather of people who are in positions of power. The reason for the mistrust of power is also drawn from article 36 of the Belgic Confession (1561): because of the depravity of human race, there is always 
mistrust of power. Therefore, power needs to be distributed among institutions such as Chapter 9 institutions, constitutional court (concourt) and community meeting or engagement. The call for a distribution of power is a partly conscious and partly unconscious recognition of the reality of the fall and the unreliability of the fallen human race (Thielicke 1969:211). The notions of power distribution are theological and constitutional imperatives because of the fallibility of humankind.

It is very problematic to divide the power of the state or to draw a clear line of detachment, for example between the judiciary and the executive: judges are appointed by the president, but the very same judges must judge against or for the president based on the merits of the case. First, there must be no concentration of power on a single point, whether in an individual (president or primer), an institution (Chapter 9 institutions) or the nation itself. Protection against the misuse of power and domination is required; hence, there must be a fair interplay between participatory democracy and representative democracy. Power must be limited for the reason that human beings are invariably tempted to abuse power. The fallen human beings are merely powerless to overcome the temptations offered by power. Second, those who are in power positions, namely the government and parliament, the ruling party and the opposition, office holders and unofficial bodies like the press and radio all require to be brought into an arrangement of reciprocal controls that will watch against power misappropriation and limit the motive for power (Thielicke 1969:214).

The theological ethics theorist, Helmut Thielicke (1969), emphasises in his book Theological ethics: politics, the necessity of the distribution of power because humans in their fallen state are incapable of handling uncontrolled, monopolised power. Such power becomes a vehicle for selfishness and self-seeking expansionism and thus poses a threat to the freedom of others. From my observation in democratic South Africa, moreover, such tendencies do exist in the local government sphere. Thielicke (1969) argues:

Our contention is that the distribution of powers is necessary because fallen man is not able to handle uncontrolled, monopolized power. Such power becomes an instrument of egoistic expansion and thus poses a threat to the freedom of others. By guarding against the misuse of power, the distribution of powers thus has the positive task of safeguarding freedom, of making freedom possible in the political sphere where a variety of power constructs necessarily arise. For this reason, which we shall show there can in fact arise within a democracy groups which prone to become totalitarian. These represent tendencies which necessarily run counter to the principle of the distribution of power. They tend toward a monopolization of power, and thus undermine the democracy within which alone they are possible. (p. 214)

According to Thielicke (1969:214), there will be some attempts to intrude the democratic principle of power distribution by constructing ways and means of manipulating such a principle. One needs to admit that there will be a tendency towards the expansion of power and that this does bear some relation to the goal sought by powerful political parties who use all the mechanisms at their disposal to concentrate power in their own direction. The distribution of powers only exists because of the legislation incorporated in the constitution of the country. This way the distribution of power is converted into cohesive leadership in a democratic state such as South Africa.

South African democracy is a multi-party representative democracy under a sovereign constitution that entrenches human rights (Republic of South Africa 1996:3). The power of the state in South Africa is generally centralised in the national circle with only limited power transferred to the provinces and local government. In the South African Constitution (Republic of South Africa 1996), there are clear constitutional and legislative provisions for community participation in governance (distribution of powers), leaving no doubt as to the existence of an unusual political commitment to notions of participatory governance. Regardless of making use of a representative democratic system, the South African Constitution (Republic of South Africa 1996) and certain laws supplement the power of elected politicians with forms of community participation (Venter \& Landsberg 2011:55).

The Municipal Systems Act 32, section 25(1) (Republic of South Africa 2000), outlined the mechanisms of participation and engagement between the government and citizens as follows:

- The local government ward committees were introduced in 1999, to allow participation and engagement of the government at the grassroots level, to allow the people to take part in running their affairs. This mechanism was meant to give the people an opportunity to inform the government about the needs of the people, and the government to conduct needs assessment, before taking decision about what the people need.

- The Izimbizo project, which is the broader community meeting, which can be a local municipal communities gathering at a particular municipal location or a district community within the district municipality, to enhance community participation. The Izimbizo project, launched in 2001 for the national, provincial and municipal executives, engaging with select communities, appeared as an offshoot of the unfolding processes of policy implementation and the need to receive direct feedback, in specific combination with policy implementation and developmental imperatives. This is another means of participatory democracy, which are, in most cases abused, to market a particular political party's ideology and not addressing the administrative issues.

- The Community Development Worker (CDW) initiative, launched in 2003, was responsible for construction of a working two-way and the participatory border between government and the people, for the sake of innovation in the development and effective governance. This initiative need to facilitate debate, initiation, and participation from the people at the local level, to engage the government, at all levels. 
In his article 'Democracy is not flawless' Modise (2012), has highlighted the following main aspects of the collaboration of participation and engagement between government and the people, referring to the Municipal Systems Act 32, section 25(1) (Republic of South Africa 2000), the Constitution of the Republic of South Africa (Republic of South Africa 1996); and Venter and Landsberg (2011) as pictured in the 2014 goals:

- the direct interface between state and government structures, such as municipal ward committees, and the IDP (Republic of South Africa 2000);

- the collaborative interface between state and both public and private representatives such as the National Economic Development and Labour Council (NEDLAC), pension funds and workplace forums;

- the promotion of democracy in terms of rights and participation that is represented by the Chapter 9 institutions (Republic of South Africa 1996);

- direct engagement between citizens and government structures, as illustrated through the Community Development Worker (CDW) initiative;

- e-communication between citizens and government structures via the Batho-pele Gateway initiative,

- direct citizen participation via the multi-purpose community centres (MPCCs), subsequently renamed the Thusong service centres. (p. 184)

The above examples attempt to illustrate that, there are different initiatives to deepen participatory democracy or attempt to distribute power among the people to avoid misuse of power by the representatives of the people in government.

Venter and Landsberg (2011:55) argue that, while the presence of a strong constitution and legislative framework portends well for public participation in South Africa, an inspection of how this demonstrates itself in practice raises questions about the political will among power holders for participatory governance. Despite the public pledges to and use of the discourse, public participation reveals instead a tendency to syndicate authority and political party power as well as close contact to decision making. They emphasise that it is clear that considerable attention needs to be paid to confirming that the policy processes of the executive are opened up for greater deliberation and input by members of the community whose lives are affected by these policy decisions.

The introduction of the municipal ward committees in 1999 was intended for such an activity within the public domain in order to give members of the public an enabling environment in which to raise matters in relation to their public and community needs. These ward committees were meant to advise the local council on matters that affect the local community. The mockery is that these committees do exist, but only for the individual and the political party's group interest, and not for public interest (tyranny of the majority or totalitarian group). The voice of the political party or leaders is received within the civil society formations like community ward committees. Friedman (1999) asserts that it would be rational for the political party to undertake to be in the process of building a challenging presence in civil society that would unavoidably support its rule. The disturbing aspect of this notion is that the political party strategists sometimes suggest that their cadres include themselves into civil society formations such as community ward committees so as to promote the party's transformation goals and agendas. The purposes may be honourably sufficient, but the consequence is an associational life that has increasingly become a political 'transmission belt' for state policies. The outcome could be demoralising. Political organisations that endeavour to absorb or coordinate civil society often destroy the participatory and voluntary spirit that constitutes its main source of strength.

In the next section, the roles, objectives and responsibilities of the community ward committees as stipulated by the Municipal Systems Act 32 (Republic of South Africa 2000) and Municipal Structures Act (Local Government 1998) will be discussed. It will be very beneficial to learn about the responsibility of the ward committee as related to their educational qualifications to execute such responsibility like decision making that requires a high level of education.

\section{Functions and powers of ward committees within a democratic society}

According to the Municipal Systems Act 32 (Republic of South Africa 2000), the foci of the community ward committee are two-folded: first, to facilitate local community participation in decision making processes that are directly affecting the local community; and second, to articulate the local community's interests and to represent those interests. It is the duty of the community ward committee to consult with the members of the community, inquire and research the aspirations, needs and interests of the local community in order to make an informed decision for the community. Drawing from the Municipal Systems Act 32 (Republic of South Africa 2000), it is the responsibility of the ward committee to liaise between the ward councillor and the community in the ward. The ward committee is the mechanism to allow a smooth flow of communication between the ward and the local council via the ward councillor.

The Municipal Structures Act (Local Government 1998) indicates that the entity of a community ward committee is to boost participatory democracy at a local government level within the dominating representative democracy. The Municipal Systems Act 32 of 2000, states that it is the imperative of the local municipalities to establish community ward committees as the mechanism of participatory democracy in South African. In case a local municipality decides to have a community ward committee, the notice, with respect to the establishment of the municipality, must reflect the collective executive system combined with the ward participatory system. The appointment of ward 
committee members must be legal and moral in nature, because it falls within the national law. The appointment must be legal in the sense that the member is a registered voting member who is a South African citizen and residing in that ward. The member must be appointed in terms of his or her competence according to the scope of the work the members are going to perform. Furthermore, the appointment must not be based on party politics.

In terms of the status of ward committees, it is proper that the appointment of members to the ward committees should go beyond party, personal and group politics. It should, however, remain loyal to the interests of the people on the ground. People serving in ward committees need to have more wisdom and knowledge than the councillor, because the ward committee acts as an advisory body. It is ethical to state that advisory boards are made up of people with specific knowledge in the field, which they are providing as advice. The work a person performs must determine what qualifications are required to perform such work. On the basis of the status, functions and powers of ward committees, members of a ward committee require certain qualifications if the ward committee is to perform its work effectively and efficiently.

\section{The critique on the possibility of participatory democracy}

Thielicke (1969:220) indicates that the system of direct participation, as distinguished from representative democracy, is possible only in very small communities, for example in the cities of the ancient Greece and the Swiss cantons where the scope of political participation is very limited. We do not have a pure form, for society's standard of what constitutes maturity allows only a limited circle to make decisions; the Greek cities, for example, excluded slaves, women and children What we have here is also in reality an early form of representative democracy, because the composite will be determined by a smaller group of persons qualified to make decisions. In practice, there has never been an instance of 'all' power residing in the people. The direct power of the people is limited to the election of representative persons or groups like ward committees, to which the concrete tasks of decision making are delegated. According to Habermas' 'liberal' view (1994:1), the democratic procedure achieves the task of encoding the government in the interest of society where the government is represented as a mechanism of public administration and society as a market-structured network of interactions among private persons. Here, politics (in the sense of the citizens' political will-formation) has the function to gather and insist on private interests against a government mechanism specialising in the administrative employment of political power for collective goals. Habermas (1994:1) urges for the full participation of the people in the democratic society.

De Gruchy (1995) argues along the same lines as Habermas (1994:1) and Thielicke (1969:220) regarding the success and challenges of participatory democracy. The success of direct participatory democracy was contingent upon the homogeneity of male householders who spoke the same language, worshipped the same deities and were willing to serve in the army in defence of the city-state. Women, slaves and foreigners living within its boundaries were excluded from the rights and privileges of citizenship. Whatever its merits, Athenian democracy was a 'tyranny of citizens'. Right from the outset, then, the debate about democracy had to do with what it means to be a citizen. Ward committee members need to be people of a particular social or educational level so that they can participate effectively as the representatives of the people at the ward level to facilitate discussion and decision making.

Evanoff (2012:192) argues that the present global system, which claims to foster democracy, in fact concentrates power in the hands of professional politicians and bureaucrats beholden to corporate interests. Bioregionalism, on the other hand, seeks to advance more participatory forms of democracy which increase direct citizen involvement in the decision-making process. At present the so-called 'democracies' of the world are moving further from, rather than closer towards, the democratic ideal. The bioregional prototypical is concerned with how our current system of representational democracy can be replaced with a form of direct democracy that reflects the interests and the will of the people. It is also concerned with how direct democracy might work not only on a local level, but also on a global scale through the employment of a confederal model of crosscultural communication. The rest of this section will endeavour to answer several objections to direct democracy and political decentralisation.

The criticisms, raised by Evanoff (2012), are similar to the concerns of the researcher throughout this article about the appointment of the ward committee members and the participation of the people through ward meetings and the Izimbizo. These criticisms are based in the form of the following questions:

- Is direct democracy even possible?

- Can everybody reach agreement?

- Do citizens have sufficient knowledge?

- Will people make the right decisions?

- How would disputes between local communities be mediated?

- Does localism not promote insularity? (p. 192)

These criticisms need to be taken into consideration whenever a ward committee is established and members are appointed to facilitate direct democracy via participation by members of the community on issues that affect the local community.

This involves a certain type of distribution of power, for the delegated persons make their decisions in light of their own conscience and their insight into the facts, although naturally within the guidelines laid down at the election. Subsequently, the people transfer the power to execute their wishes as laid down in the guidelines of the party platform to their 
representatives. The people to whom the power is delegated must be mature in terms of the operation of the country's law. The community members must know how to deal with the people. This separation of power between the people and their representatives is of great significance, because power without any or very limited insight, led by the ignorant instincts of the masses expresses serious distrust. (Thielicke 1969:221).

Therefore, capacity is needed for the people to administer the political affairs of the cities in a participatory or representative democracy. Quite apart from the fact that in certain larger states the direct participation of the people as a whole would be technically impossible, the decisions to be reached are also too complicated for any but professional politicians or persons with special competence to take on such issues. Again, the people as a whole are hardly qualified, because many decisions demand a degree of disciplined objectivity and therefore an ethical quality, which cannot reasonably be expected of the general public, but only of a circle of persons who measure up to the more stringent technical and ethical demands (Thielicke 1969:221).

People are qualified to make real decisions only when they can grasp and formulate the point at issue, but this is not possible for the general public. The Platonic argument is that the masses are driven rather by passion than by reason and hence are unable to make intelligent decisions themselves. Instead, decisions should be made by informed 'experts' who, in modern industrial societies, are primarily technocratic elites. The difficulty with the Platonic view is that it conflates moral decision-making capacity with technical knowledge. Although citizens may not be able to understand all the technical aspects of the given policy, they may still have a very intimate knowledge of the effects such policies have on their own lives, on the lives of others and on the environment (Fischer 2000).

While information can be solicited from experts when necessary, final decisions about policies can still be made by the citizens themselves. In any event, it is commonly recognised that democracy cannot function in the absence of an educated populace that is well-informed about issues and morally sensitive to the implications of the policies they implement. Educators and experts have an obligation not only to disseminate technical knowledge, which, in the context of the present system, often simply socialise people into the goals and procedures of the capitalist paradigm, but also to stimulate reflective thought on the social and ethical implications of the knowledge they impart (Evanoff 2012:198)

\section{Conclusion}

In conclusion, one might say that, instead of concentrating power in the centralised institutions at the national, provincial and local government level, ward committee establishment seeks to disperse both political and economic power to the local level of the communities via the ward committees. In this model, horizontal communication would involve all the members of a local community (not just the elites) and vertical communication would be from the bottom up (from the local to the national). The communication process would therefore be the exact opposite of the current situation in which most horizontal communication takes place only between elites (at the provincial and national level) and most vertical communication is from the top down (from the national or provincial to the local level). This communication needs to be kept balanced in terms of knowledge, influence and gender of ward committee members. Power will then be distributed evenly to the people and used constructively.

\section{Acknowledgements Competing interests}

The author declares that he has no financial or personal relationships which may have inappropriately influenced him in writing this article.

\section{References}

Belgic Confession, 1561, viewed 21 January 2017, from https://www.crcna.org/ welcome/beliefs/confessions/belgic-confession

Bonhoeffer, D., 2012, 'State and Church', in W.T. Cavanaugh, J.W. Bailey \& C. Hovey (eds.), An Eerdmanns reader in contemporary political theology, pp. 286, Wm. B Eerdmans Publishing Co, Grand Rapids, MI.

Craythorne, D.L., 2006, Municipal administration, 6th edn., Juta \& Company, Cape Town.

De Gruchy, J.W., 1995, Christianity and democracy, David Phillip, Cape Town. https:// doi.org/10.1017/СВ09780511627927

Evanoff, R., 2012, 'Bioregionalism and direct democracy on global scale', in L.C. Bargeliotes \& K. Wang (eds.), A journal for philosophy and inter-disciplinary research, vol. XXII/ii, pp. 185, Olympic Center for Philosophy and Culture, Ancient Olympia.

Fischer, F., 2000, Citizen, experts, and environment: The politics of local knowledge, Duke University Press, Durham. https://doi.org/10.1215/9780822380283

Friedman, S., 1999, 'Agreeing to differ: African democracy - its obstacles and prospects', Social Research 66(3), 825-858.

Habermas J., 1994, Constellations, vol. 1, no 1, Blackwell Publishers, Oxford UK. https://doi.org/10.1111/j.1467-8675.1994.tb00001.x

Hunsinger, G., 2012, 'Introduction', in W.T. Cavanaugh, J.W. Bailey \& C. Hovey (eds.), An Eerdmanns reader in contemporary political theology, pp. 271, Wm. B Eerdmans Publishing Co, Grand Rapids, MI.

Local Government, 1998, The Municipal Structures (Act 117 of 1998), Juta \& Company Limited, Cape Town.

Metz, J.B., 2012, 'Theology in the New Paradigm: Political theology', in W.T. Cavanaugh, J.W. Bailey \& C. Hovey (eds.), An Eerdmanns reader in contemporary political theology, pp. 316, Wm. B Eerdmans Publishing Co, Grand Rapids, MI.

Modise, L., 2012, 'Democracy is not flawless: South African Perspective', in L.C. Bargeliotes \& E. Demenchonok (eds.), Proceedings of the Ninth World Congress, pp. 177, Olympic Center for Philosophy and Culture, Ancient Olympia.

Republic of South Africa, 1996, Constitution of the Republic of South Africa (Act 108 of 1996), Government Printer, Pretoria.

Republic of South Africa, 2000, Municipal Systems (Act 32 of 2000), Government Printer, Pretoria.

Raadschelders, J.C.N., 2003, Government: A public administration perspective, Routledge, New York.

Schmidt, M.G., 2002, Political performance and types of democracy: Finding from comparative studies, Blackwell, Oxford.

Thielicke, H., 1969, Theological ethics: Politics, Eerdmans, Grand Rapids, MI.

Venter, A. \& Landsberg, C., 2011, Government and politics in South Africa, Van Schaik Publishers, Pretoria. 